\title{
Postal Motor Trucks
}

\section{How They Can Be Made to Pay for the Roads on Which They Will Run By C. H. Claudy}

\section{$\mathrm{N}^{\circ}$}

T least among the strange developments which the

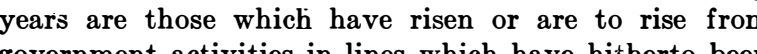
geve held entirely in State hands or in the hands of private interests. "C'est la guerre" is a reason for anything in France-perhaps the mental awakening of this country in peace activities is also "because of the war." However that may be, it is as pleasant as it is strange to find the Federal Government proposing to take an active part in road construction, not because of any private economic need of good roads, but because it, the Federal Govern ment, finds that by so doing it can make a handsome profit for itself and at the same time serve its people the better. It is as unusual as it is interesting to find the Federal Government making an exhaustive study of the cost of motor truck operation when such vehicles are used for the transportation of both mail and miscellaneous freight (parcel post) and it is as queer as it is unexpected to find constructive initiative cutting through red tape and producing results of farreaching economic value in a totally new development of highways, moto cars, mail transportation and food transportation.

All of which has to do with the revolutionary experiments conducted by the Post Office Department in the establishment and the successful operation of eight motor-truck parcel-post and mail routes, the statistical studies resulting therefrom, and the proposal to extend this evidently necessary and profitable service, first throughout the states east of the

The eight routes referred to are between Philadelphia and Atlantic City, between Baltimore and Solomon's Island, between the capital and Leonardtown, between Washington and Baltimore, between Baltimore and Lancaster, between Philadelphia and Washington, between Savannah and Statesboro and between Columbus and Zanesville.

For a moment and before digesting any dry-as-dust statistics, let the reader admit for the sake of argumen that these routes have proved themselves very highly profitable. His next natural question is "if the government can operate parcel post automobiles with a very large margin of profit, why can't commercial firms do the same thing? And if the commercial firm can do it why should the United States government jump into the commercial game and compete with existing methods of transportation, freight, express, rail, water?"

The answer is very simple. The United States and only the United States can carry first class mail. And there is no other commodity which pays such a price for its transportation. At three cents an ounce, first class mail brings in $\$ 960$ per short ton. But first clas mail actually brings a much higher rate, for the average letter on which three cents is paid weighs less than half an ounce. First class mail easily averages $\$ 2,000$ a to or a dollar a pound. Not only can no commercial firm carry mail but no commercial firm can carry any freigh at such a price, because no one will pay that price for anything except mail.

In establishing any new system of transportation, it i necessary to gain the confidence of the people served, an operation which takes time. No motor truck route, government or private, is going to be a paying investment at the start. It must wait, and run, and run, an a wait. But it doesn't have to because it begins to carry first-class mail from the date of establishment of such a route, which mail more than pays for the expense without counting any profit to be made in money by the government, or in service by those who use the motor trucks to send market produce to sales centers.

Consider for a moment something of the financial en of such routes and what it figures in dollars and cents.

In the first five months of this year, the eight route mentioned carried a total of $\$ 152,237.74$ of mail-all classes. The total operating expenses were $\$ 27,130.98$. The total profit was $\$ 125,069.26$.

There was a loss of $\$ 860.52$ on the PhiladelphiaAtlantic City line. The other seven routes showed individual profits running from $\$ 255.83$ (SavannahStatesboro) to $\$ 35,764.21$ (Washington-Leonardtown)

Naturally, statistics of profit are worthless unless there is a very clear statement of just what "operating expense" may be. The Post Office Department doesn' beg the question in the least. And the statistical study of actual operating cost is a matter of great interest, not only to the "folks back home" who may want to say a word to their representatives about the extensions of such a service to their own doors, but to owners and operators of commercial vehicles, who can surely find in this presumably unbiased examination a standard which they can set, or a mark at which they can shoot, to beat if possible.

Cost of operation is classified by the department under the following heads:

Gasoline, grease and oil, tires and tubes, repairs (labor and material), accessories, garage, salaries, supervision, interest, depreciation and miscellaneous. The study is further extended to total cost, total mileage, cost per mile and miles per gallon of gas.

For the period of six months, from December 1st, 1917, to May 3d, 1918, the eight routes. mentioned consumed 21,636 gallons of gas at a cost of $\$ 5,325.64$. Grease cost $\$ 823.89$, tires and tubes $\$ 3,426.92$, repair labor $\$ 1,388.82$ and repair material $\$ 528.08$. Accessories figured $\$ 116.45$, garage $\$ 864.86$, salaries $\$ 8,428.73$, supervision $\$ 3,439.07$, interest $\$ 323.11$, depreciation $\$ 3,032.22$ and miscellaneous $\$ 1,401.83$

This makes the total cost $\$ 29,099.63$ for a total mileage of 201,811 and a total cost per mile of $\$ .1442$. The average miles per gallon of gas were 9.33 .

It is now easily to be seen how these routes can operate at a great profit from small mail income. In the case of the Washington-Leonardtown run, for instance, which is about 75 miles, at 15.75 cents per mile (in this run the cost was above the average) the cost of a trip is but $\$ 11.82$ and less than 25 pounds of first class mail will pay that sum at the full rate of three cents an ounce. As a matter of fact 12 pounds of first-class mail of average weight will pay the cost. And the capacity of the machine is many, many times 12 pounds-all the rest of the space and weight carrying ability can be devoted to parcel post at parcel post rates; eggs, fish, vegetables, chickens, anything - to be brought from a production to a consumption center in the only quick way now feasible between two centers

The postoffice finds that the efficient and economical (Concluded on page 136)

\section{Correspondence}

The editors are not responsible for statements made in the correspondence column. Anonymous communications cannot be considered, but the names of correspondents will be withheld when so desired.

\section{Why the Gow Crossed the Road}

To the Editor of the ScIentific American:

Why the cow crossed the road has been a standard conundrum for ages. From time immemorial this contrary beast and its companion in misfortune, the chicken, have crossed the road on the run at risk of life liberty and the pursuit of happiness, both their own and of legions of provoked drivers. Why is this?

It is submitted that the answer lies in the fact that cows and some other animals, chickens and some othe birds, have monocular single vision, as you have taught us to define it in the Dr. Bates controversy. In othe words, each eye may be focussed on a different object without mental confusion.

When a cow faces an object, both eyes may with ease be focused on it. When the object is at the side or rear, one eye may be focused on it, while the other is viewing objects in quite a different direction. Evidently the animal may direct attention to one object with both eyes, or to two objects with different eyes, or it may in hibit one eye and direct and concentrate attention with the other toward some object of fear or fancy.

In advancing in a car toward cows standing in the roadway, it will be noticed that those facing the car usually turn to one side and let the car pass; those with side toward car will, if on, say, the right side of the road, run and attempt to cross to the left side; those with head away from the car will usually run down the roadway ahead, turning off at one side or the other.

The reason why the cow or chicken on the right side of the road turns to cross over to the left, and vice versa is, I suggest, because the eye of the animal which sees and appreciates the danger of the advancing car is by in stinct kept on the dangerous object. To turn to the right and escape would blind the animal during the period of turning, and this she will not willingly do. But if she runs across the road in frent of the car, the ey with which she first observed it will keep it clearly and continuously in view and, she thinks, allow her to escape the impending danger. Even when safely across, if turned around, by encountering a fence or by chance, so as to perceive the enemy with the other eye, I have seen her run for dear life to recross the road to the side whence she is just come.

The instinctive action, originally protective, is thu made a source of danger to the animal. The chicken with monocular vision, labors under the same hallucina tion; it, too, thinks that the danger may be avoided by running with all its might, keeping the enemy all the time in view with the eye that was originally turned toward it. Thus, truly, the cow crossed the road because she crossed the road.

H. L. WHITED.

\section{Making Tin Plate in Australia}

THE supplies of tin plate for Australasia, the value of which amounts to over $\$ 12,000,000$ per year, are drawn wreat Britain and America; but recently the lack of shipping and other difficulties have led to a serious shortage in deliveries. A leading Australian producer of steel has accordingly arranged to establish tin-plate works which will eventually supply the whole of the Antipodal demand. Plenty of tin is available in Australia as well as the necessary steel. The company in question, in addition to supplying steel for Australia, has sent considerable quantities of munitions steel to Great Britain and has also opened up trade with South Africa by supplying 20,000,000 tons of steel rails.

\section{The United States Employment Service}

$\mathrm{O}^{\mathrm{N}}$ August 1st, the new arrangement went into effect, centralizing in the United States Employment Service of the Department of Labor the business of supplying with common labor all war industries having a payroll of more than one hundred men. With this date, all independent recruiting by manufacturers of labor in this class will cease. This is in accordance with the decision of the War Labor Policies Board, approved by the President June 17 th.

The necessity for some such step has long been developing. In no other way, apparently, was it possible to overcome a perilous shortage of unskilled labor in the war industries. This shortage was aggravated by an almost universal practice of labor stealing and poaching. It is on its face an impossible situation when in Pitts- burgh, for example, there are advertisements calling for men to go to Detroit, while in Detroit street cars there are posters' asking men to go to Pittsburgh. This same condition is apparent all over the country and in the consequent shifting of labor a great part of our war strength is dissipated. In some instances the labor turnover is as high as one hundred per cent a week, which is obviously ruinous.

While the restrictions against private employment of labor apply only to common labor at the present time these restrictions will, as soon as possible, be extended to cover skilled labor also. In the meantime, recruiting of skilled labor for war production will be subject to Federal regulations now being prepared. Non-essential industries will of necessity be drawn upon to supply the labor required for war work; but the withdrawal will be conducted on the most equitable basis which can be devised, in order to afford the individual employer the maximum of protection.

A survey of labor requirements is being made; and in order that local interests may be protected, rulings have been made that no labor shall be transported out of any community without the approval of the State Director, nor from one state to another without the approval of the central bureau in Washington. All efforts will be made to discourage movements from community to community or from state to state by other ervices.

For the present, the new service does not apply to labor which is not directly or indirectly solicited; the man who wants to get out and hunt a new job for himself will be free to do so. It does not apply to labor for the railroads, or for farms, or for non-war work, or for establishments whose maximum force does not exceed one hundred men. Whether it will be extended to any of these classes will doubtless depend upon its success with the class for which it is designed, and the extent to which these unfederalized classes are found ultimately to conflict with the immediate needs of the big war industries. In any event, it seems probable that the recruiting of farm labor may be left where it is now, in the hands of the Department of Agriculture.

The general policy of the new service will be to keep any community from being drained of labor, and, so far as possible, to use local supply for local demands. The situation, however, is such that in certain cases men may have to be transported over distances. 


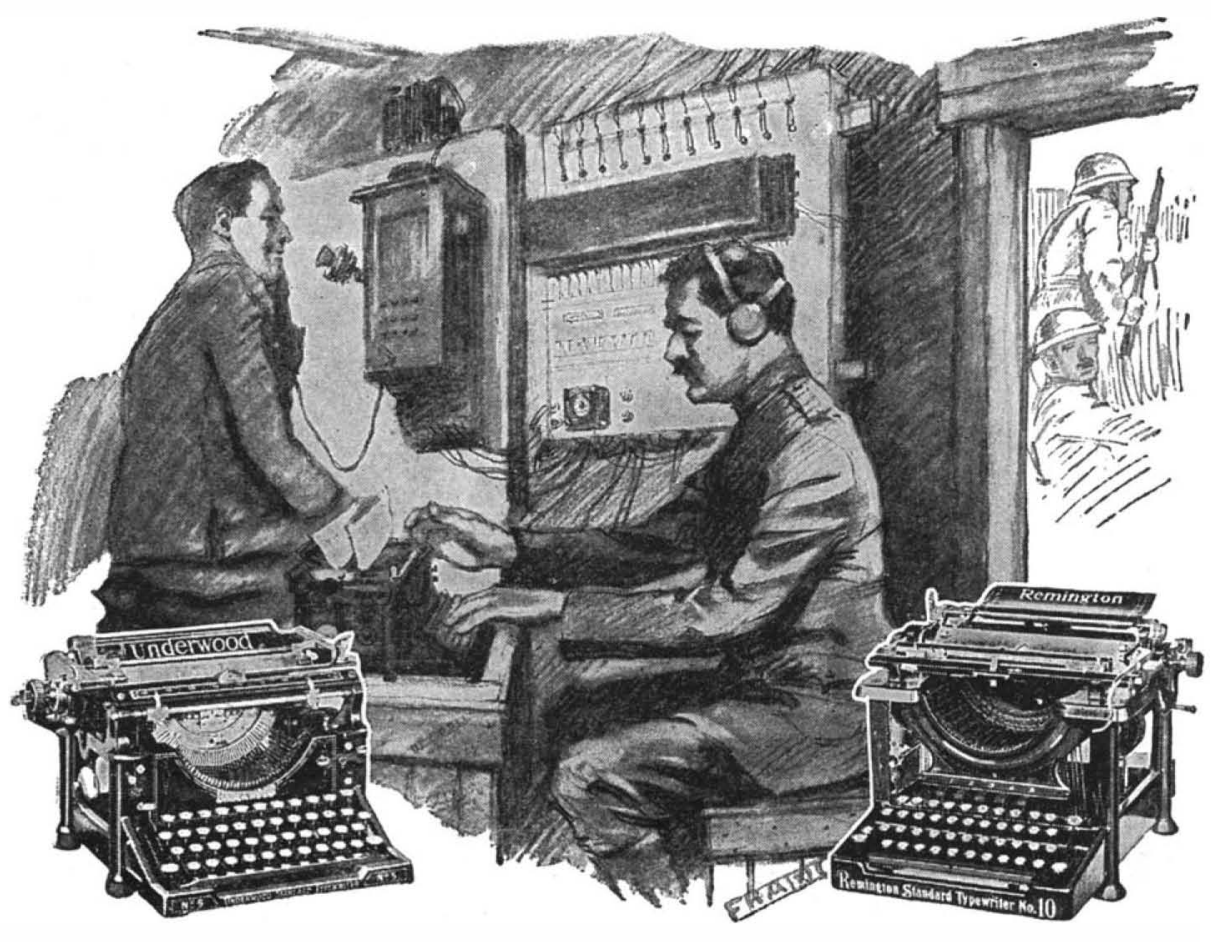

\section{"At 5:08 in the Morning You Are to Launch Your Attack"}

In the damp muggy huts-perhaps not more than a stone's throw from No Man's Land-the typewriters click out the orders which send our brave lads cheering and charging into the ranks of the Hun.

In an atmosphere which would quickly rust into ordinary metal the Underwood and Remington operate perfectly day af ter day - with scarcely any attention save an occasional application of oil.

A trip into the war zone reveals hundreds of iron and steel products which withstand the drenching rains of France without a sign of rust - because they are protected from the elements by the Parker Process.

Wide Variety of Metal Articles

\section{Rustproofed by the Parker Process}

This endorsement by the Allied Governments merely confirms the experience of the leading American manufacturers who have been rustproofing their products by the Parker Process for several years. Among the everyday metal articles which are rustproofed by the Parker Process are: Building Supplies, Automobiles, Motor Trucks, Motor Accessories, Electrical Equipment, Typewriters, Farm Implements, Ranges and Stoves, Steel Furniture, Sporting Goods, Phonographs, Dental Supplies, Railway Supplies, Telephone Equipment, Ornamental Iron Work, Arms and Ammunition.

\section{A Practical Book On Rustproofing for You}

Manufacturers and industrial executives who use steel or iron in their products will be interested in reading the Parker Process book. This not only explains what the Parker Process isand how it does its work, but also tells who the concerns that are using it are-and how easily you can adopt it for your own product without in any way interfering with your present production plans. Address

PARKER RUST PROOF COMPANY OF AMERICA Praprers

DETROIT, MICHIGAN, U. S. A.

समranter
The Current Supplement

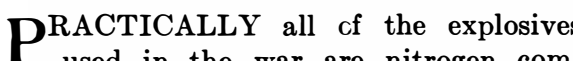
$P$ used in the war are nitrogen compounds, and considering the immense
quantities burned every hour of the day by quantities burned every hour of the day by easily appreciated what an important matter an adequate supply of ammunition is. Our original source was Chile saltpeter but dependence on this is precarious, especially in view of the shortage of ships. Various other sources of supply are now possible, and an excellent review of these will be found in a paper on The Nitrogen currem in Relation to the War in the SUPPLEMENT, No. 2224, for August 17th Those who have made a study of the American Indians are aware of the fact that their medical practice did not consis wholly of conjuring tricks and invocation of spirits, but that they had a very considerable knowledge of the medical propertheir remedies possessed real value, although but scant records have been prethough but scant records have been pre-
served. An article on Indian Medicines served. An article on Indian Medicines
gives the results of a careful study of the remedies that were obtained from trees, and it is accompanied by a number of illustrations. Familiar Scenes in a Modern Shipyard shows operations in woode ship building, with brief notes on the subjects illustrated. Bread is the staff of life, but owing to the present excessive
demands for wheat, which apparently greatly exceeds the possible production, under existing conditions, substitutes are being carefully considered. Among these is corn, a material which, although consumed by human keings to a large extent in America, is but little known, or understood, America, is but little known, or understood,
by people of other countries. In an article by people of other countries. In an article on Corn Is King, the question whether thi grain will become the base food of the
world is discussed, in view of its prolific yield, and ease of culture. The Madsen Automatic Gun describes and illustrates in detail a machine gun that is highly thought detail a machine gun that is highly thought
of abroad, and a study of its construction of abroad, and a study of its construction
will give an excellent idea of the principles will give an excellent idea of the principles involved in this class of weapon. Th
paper on Ports and Terminal Facilities is concluded in this issue.

\section{Postal Motor Trucks}

(Concluded from page 127)

operation of any such service is dependent upon three primary factors: The highway, the vehicle and the commercial convenience of the patron. The two latter are variable factors-some trucks are better than others and some communities take more kindly to parcel post than others.

But the highway is a fixed factor. Its cost, location, maintenance are all matters
of figures. Hence a great program can be considered in definite figures.

The use of state highways by government owned equipment for profitable enterprise without compensation to the tates except in improved mail facilities to residents is not equitable. The Federal government may be under a moral obligation to reimburse the states in some substantial manner. The post office believes this can be done with benefit to the states and at the same time further increase the profitable possibilities to the Federal gover ment by building and maintaining roads.

A joint resolution under consideration in Congress authorizes the use of not more than fifty per cent of the gross earnings of motor truck parcel post routes for the construction and maintenance of the highways on which the service is or may be established.

A survey of possible routes east of the Mississippi indicates approximately 7,500 miles of highway to be covered, of which at least 5,000 miles would be essential to successful motor truck service.

Five thousand miles of permanent roads, exclusive of bridges and municipal streets, lready completed and not included in contemplated construction, would cost about $\$ 20,000$ per mile, using every possible economical method of construction, including convict labor where available, prisoners of war, and local road making materials. The entire 7,500 miles would cost about $\$ 150,000,000$.
One thousand of a possible 5,000 cars, operating east of the Mississippi should earn (based upon statistics obtained where keen competition from available means of conveyance appears) $\$ 40,000$ mer a convey once a total of $\$ 40,000,000$ nnually $\$ 5,000,000$ for cost of operation of cars, $\$ 10,000,000$ for indirect cost of transportation of mails to and from the routes, and $\$ 5,000,000$ for extensions and additional service. The remainder, $\$ 20$,000,000 per annum, could be applied for the con Highways.

The Post Office Department does not believe 1 his idea at all impractical. It points out that 10,000 routes earning $\$ 40,000$ each year would produce $\$ 40 C^{\circ}$,000,000 per annum or more than the total annual postal revenues at this time. There are $6 C, 000$ rural and star routes in operation in the Postal Service. Thereore, 10,000 motor truck routes is not an unusual number or a startling one. If each route transported but 100 pounds of first-class mail daily the revenues would be $\$ 45,000$ per year. Of the total of 10,000 possible routes at least 1,000 can be lo ot interfere with existing postal revenue and surplus earnings of those 1,006 routes would in due time build and maintain the proposed Federal roads.

How We Are Training Our Specialists in Gas Warfare

JNTRUCTORS in gas defense are to be trained at Camp Humphreys, Va., the new camp of the Engineer Corps. The lans contemplate a course of instruction f about a month's duration, at the end of which the graduates will be fitted to become division gas officers, taking charge for work of preparing American soldiers for defense against gas attack. About The gas officers will be trained at a time. ts work.

The gas officers who now are on duty with the various divisions received their training at the camp at American University, Washington, D. C. These officers completed their training last November and were at once assigned to duty at the different National Army and National Guar National Army and National the need rising for additional officers, the the need rising for additional officers, the
school was established at Camp Humphreys Most of the gas officers are commissioned first lieutenants. Special qualification are necessary in order to qualify for this service. Besides having a thorough knowledge of chemistry, gas officers must be ble to impart their knowledge to others, and, possess ability to maintain discipline. Under the tutelage of the gas officer who have been at the various camps for the past six months the troops which are going forward to France are well posted on methods of combating gas attacks. All the men are supplied with gas helmets, but possession of these helmets is only the first step in safeguarding the troops from the gas menace. Under the divisio gas officers and others assigned by each regiment as assistant instructors, the enisted men and officers are drilled in the use of masks, taught how to detect the presence of gas and given actual experience shells and cloud attacks, used of ten at night in connection with high explosives, help to make the training realistic. The enlisted men are given practical training, but company and regimental officers have an opportunity to attend lectures and ceive theoretical instructions.

The United States has been able to build on the experience of the British and French to whom gas attacks were unknown whe they entered the war. No Americans have gone to the front without The field training section of the gas defense service was formerly under the Sanitary Corps but now is under the Engineers. A group of British gas officer has been in this country since last summe One of these men has been at each of the training camps, advising and assisting the division gas officer. 